\title{
To study the short-term outcome and risk factors for premature neonate born at Dr. Bhimrao Ambedkar Memorial Hospital, Raipur, Chhattisgarh, India
}

\author{
Phuljhele S. ${ }^{1}$, Bichpuria P. ${ }^{2 *}$, Yusuf S. ${ }^{3}$, Singh A. ${ }^{4}$ \\ DOI: https://doi.org/10.17511/ijpr.2020.i04.02 \\ ${ }^{1}$ Sharja Phuljhele, Professor and HOD, Department of Pediatrics, Pt J.N.M. Medical College, Raipur, Chhattisgarh, India. \\ 2* Prachi Bichpuria, Assistant Professor, Department of Pediatrics, Pt J.N.M. Medical College, Raipur, Chhattisgarh, India. \\ 3 Samreen Yusuf, Postgraduate, Department of Pediatrics, Pt J.N.M. Medical College, Raipur, Chhattisgarh, India. \\ ${ }^{4}$ Abha Singh, MS, Department of OBG, Pt J.N.M. Medical College, Raipur, Chhattisgarh, India.
}

Background: Prematurity is the leading cause of perinatal morbidity and mortality worldwide affecting $5-10 \%$ of births. Preterm neonates have a 120 times higher risk of death than neonates. Methods: This is a prospective hospital-based observational study, conducted over a period of 1 year (March 2018 - March 2019), including a total of 1472 preterm babies. Results: A total of 1472 preterm were born during the study period. Preterm male: female was $1.1: 1$. Common risk factors noted were multiple pregnancies (28.46\%) followed by pre-eclampsia $(27.03 \%)$. A total of $66.71 \%$ of neonates were born beyond 34 weeks of gestation, $60.46 \%$ were having birth weight between 1500 and $2499 \mathrm{gm}, 18.14 \%$ were very low birth weight (VLBW) and 4.35\% were extremely low birth weight (ELBW). A total of 545 (37.02\%) required NICU admission. Major morbidities noted were respiratory distress syndrome (55.59\%) followed by sepsis $(30.64 \%)$, perinatal asphyxia $(11.19 \%)$, neonatal jaundice $(10.64 \%)$ and retinopathy of prematurity (9.91\%). A negative correlation was noted between gestational age and duration of stay in NICU $(r=0.98, p=0.022)$. Birth weight and gestational age of neonates were significantly associated with the treatment outcome $(p=0.000)$. Very low birth weight neonates had the highest mortality $(40.85 \%)$ followed by ELBW (28.05\%). Mortality of $11.14 \%$ was noted with respiratory distress syndrome $(10.83 \%)$ being the major cause followed by sepsis $(8.07 \%)$. Conclusions: The most common maternal risk factors noted were multiple pregnancies, preeclampsia, eclampsia, antepartum hemorrhage, and gestational hypertension. Common morbidities observed in preterm babies were respiratory distress syndrome, sepsis, perinatal-asphyxia, and neonatal-jaundice.

Keywords: Pre-term, Risk factors for prematurity, Short term outcomes

Corresponding Author

Prachi Bichpuria, Assistant Professor, Department of Pediatrics, Pt J.N.M. Medical College, Raipur, Chhattisgarh, India.

Email: prachithegem@gmail.com
How to Cite this Article

Phuljhele S, Bichpuria P, Yusuf S, Singh A. To study the short-term outcome and risk factors for premature neonate born at Dr. Bhimrao Ambedkar Memorial Hospital, Raipur, Chhattisgarh, India. Pediatric Rev Int J Pediatr Res. 2020;7(4):166-173. Available From

https://pediatrics.medresearch.in/index.php/ijpr/arti

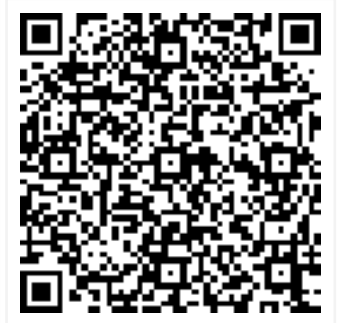
cle/view/591

$\begin{array}{cc}\begin{array}{c}\text { Manuscript Received } \\ 2020-04-06\end{array} & \begin{array}{c}\text { Review Round } \mathbf{1} \\ 2020-04-17\end{array} \\ \text { Conflict of Interest } \\ \text { No } & \text { Funding } \\ \text { Nil }\end{array}$

Review Round 2
2020-04-23
Ethical Approval
Yes

Review Round 3

Accepted 2020-04-27 (c) 2020 by Sharja Phuljhele, Prachi Bichpuria, Samreen Yusuf, Abha Singh and Published by Siddharth Health Research and
Social Welfare Society. This is an Open Access article licensed under a Creative Commons Attribution 4.0 International License https://creativecommons.org/licenses/by/4.0/ unported [CC BY 4.0]. 


\section{Introduction}

Premature birth or preterm birth is defined as the birth occurring after 20 weeks and before 37 weeks of gestation by the World Health Organization (WHO) [1]. It is a syndrome associated with neonatal morbidity, which has adverse consequences for long-term health [2]. High neonatal mortality rates are the sum total of complications during the lives of premature infants [3]. Every year, more than 1 in 10 babies; an estimated 15 million babies, are born too early. Almost 1 million children die each year due to complications of preterm birth. The total burden of preterm birth was estimated to be 3,519,100 in 2010, with India harboring the highest number of preterm subjects. Of all early neonatal deaths (deaths within the first 7days of life) that are not related to congenital malformations, $28 \%$ are due to preterm births [4].

The rate of preterm birth in developed countries has risen, rather than fallen, over time [5] Moreover, the survival rates for very early preterm births have increased because of technological advances and the collaborative efforts of obstetricians and neonatologists. The brain[6] and lung,[7]even when most organs are immature, are especially susceptible to the consequences of preterm birth, leading to high rates of long-term neurological and health problems. The predisposing event causing pre-term birth remains unclear, although the etiology is thought to be multifactorial. Causal factors linked to preterm birth include medical conditions of the mother and fetus, genetic influences, environmental exposure, infertility treatments, behavioral and socioeconomic factors, and iatrogenic prematurity [8].

In 2010 [9] more than one in 10 of the world's infants, of more than 15 million children, were born prematurely and more than a million of those children died secondary to complications associated with premature birth. Although preterm births at 32-36 weeks' gestation are five times more common than births before 32 weeks' gestation, their public-health effect has not been well studied [10]. There are substantial mortality and neonatal morbidity in late preterm births. There are higher rates of temperature instability, respiratory distress, apnoea, hypoglycemia, seizures, jaundice, kernicterus, feeding difficulties, periventricular leukomalacia, and re-hospitalizations in preterm infants, compared with infants born at term $[11,12$
-14]. Preterm infants also make up an important fraction of infant deaths [10].Gestational age exerts the greatest influence on outcomes of preterm births. Earlier use and an increase in of antenatal corticosteroids, [15] assisted ventilation, and surfactant, [16] and changing attitudes towards intensive care, [17] result in survival rates for very preterm births, especially those born before 28 weeks' gestation, improving strikingly by the mid1990s [18]. Fetal growth restriction affects survival rates-for any gestational age, growth restriction of the infant is related to the mortality rate, especially in very preterm infants $[19,20,21]$.

The single most important cause of death in the first month of life is prematurity and in the neonatal period, it is a factor in over $75 \%$ of pediatric deaths. Prematurity is a global health problem being the second leading cause of death in children under five years old [22]. Moreover, prematurity is associated with learning and motor disabilities and with visual and hearing impairment, contributing to approximately half of the disabilities in children.

\section{Material and Methods}

Type of study: Prospective hospital-based observational study.

Study setting: Department of Paediatrics, Pt JNM Medical College, and Dr. B R Ambedkar Memorial Hospital Raipur, Chhattisgarh, India.

Study period: March 2018 - March 2019.

Study population: A total of 1472 preterm babies were studied.

Inclusion criteria: All preterm deliveries at BRAM Hospital during the study period.

Exclusion criteria: Out born preterm babies admitted in NICU.

Methodology/Data collection: Sociodemographic information was collected by using the pretested and predesigned structured proforma by interview technique. Gestational age was assessed using the modified New Ballard score. Medical records were examined to note the pregnancy history of mothers. Medical records in NICU were examined to note down the medical complications and birth weight of preterm neonates.

Data collection was divided into 3 parts:

- Demographic and Socio-economic information of mothers and family. 
- Complications and antenatal history of mothers.

- Medical history of preterm newborns.

\section{Outcome variables:}

Primary variables: Survival, NICU admission, duration of stay.

Secondary variables: Major morbidities prior to hospital discharge.

\section{Statistical analysis}

- All relevant data were entered into predesigned proforma and analyzed (with the help of statistician) using Microsoft SPSS software for windows TM Version 22.0, IBM TM Corp NY, and Microsoft excel TM 2010, Microsoft Inc USA.

- Data were expressed as a percentage and mean $+/-$ SD.

- Pearson correlation analysis was performed to check the correlation between categorical variables.

- Fischer's exact test or Chi-square test was used to analyze the significance of the difference between the distributions of the data.

- P-value < 0.05 was considered as statistically significant.

\section{Results}

A total of 1472 preterm neonates were delivered during the study period, out of which $54 \%$ were males and $46 \%$ were females.
885 (60.05\%) preterm were delivered by normal vaginal delivery (NVD) and 587 (39.95\%) preterm were delivered by Lower Segment Caesarean Section (LSCS).

Mothers who had complications during pregnancy were 418 (28.40\%). Of them, 119 (28.46\%) had multiple births, $113(27.03 \%)$ had pre-eclampsia, $78(18.66 \%)$ had eclampsia, 40 (9.56\%) had antepartum haemorrhage, 35 (8.37\%) had gestational hypertension and 33 (7.89\%) had Oligohydramnios.

Out of 1472 preterm, 45 (3.06\%) were born < 28weeks, $445(30.23 \%)$ were born 28-'34 weeks and $982(66.71 \%)$ were born $>34$ weeks of gestation. Of all the preterm, 64 (4.35\%) were extremely low birth weight (ELBW; <1000 grams), 267 (18.14\%) were very low birth weight (VLBW; 1000-1500 grams), 890 (60.46\%) were low birth weight (LBW; $1500-2500$ grams) and 250 (16.98\%) had normal birth weight.

Only $23(1.56 \%)$ preterm had congenital anomaly and the most common congenital anomaly note was acyanotic CHD (21.5\%) and cleft lip and palate (21.5\%).

Out of 1472 preterm, 545 (37.02\%) were admitted in NICU, 34 (6.24\%) were < 28 weeks of gestation, 304 (55.78\%) were 28-34 weeks and 207 (37.98\%) were $>34$ weeks. If the birth weight of the preterm admitted in NICU is observed, 64 (11.56\%) were ELBW, 207 (38.17\%) were VLBW,

Table-1: Maternal Risk factors and complications of mothers giving birth to pre-term newborns.

\begin{tabular}{|l|l|l|l|l|l|l|l|l|l|}
\hline \multicolumn{1}{|c|}{ Age $($ years $)$} & $\mathrm{f}(\mathrm{N})$ & Percentage & Weight $(\mathrm{Kg})$ & $\mathrm{f}(\mathrm{N})$ & $\%$ & \multicolumn{1}{|c|}{ Complications } & $\mathrm{f(N)}$ & $\%$ \\
\hline $18-21$ years & 352 & 23.91 & $46-52 \mathrm{~kg}$ & 24 & 1.63 & Multiple births & 119 & 28.46 \\
\hline $22-25$ years & 680 & 46.2 & $53-59 \mathrm{~kg}$ & 176 & 11.96 & Pre-Eclampsia/Eclampsia & $113 / 78$ & $27.03 / 18.66$ \\
\hline $26-30$ years & 319 & 21.67 & $60-66 \mathrm{~kg}$ & 772 & 52.45 & Antepartum Hemorrhage & 40 & 9.56 \\
\hline $31-35$ years & 88 & 5.98 & $67-73 \mathrm{~kg}$ & 429 & 29.14 & Gestational Hypertension & 35 & 8.37 \\
\hline $36-40$ years & 30 & 2.04 & $74-80 \mathrm{~kg}$ & 67 & 4.55 & Oligohydramnios & 34 & 8.13 \\
\hline$>41$ years & 3 & 0.2 & $>80 \mathrm{~kg}$ & 4 & 0.27 & ShortStature/Bad obstetric history & $16 / 16$ & $3.83 / 3.83$ \\
\hline Total & 1472 & 100 & Total & 1472 & 100 & Other risk factors & 71 & 14.66 \\
\hline
\end{tabular}

Table-2: Gestational age of preterm newborns.

\begin{tabular}{|l|l|l|l|}
\hline \multicolumn{1}{|c|}{$\begin{array}{c}\text { Gestational age of } \\
\text { newborns }\end{array}$} & \multicolumn{1}{c|}{$\begin{array}{c}\text { Total } \\
\text { delivered }\end{array}$} & \multicolumn{1}{|c|}{$\begin{array}{c}\text { Admitted in } \\
\text { NICU }\end{array}$} & \multicolumn{1}{|c|}{ Death } \\
\hline$<28$ weeks & $45(3.05 \%)$ & $34(75.5 \%)$ & $23(51.1 \%)$ \\
\hline $28-34$ weeks & $445(30.23 \%)$ & $304(68.31 \%)$ & $\begin{array}{l}112 \\
(25.16 \%)\end{array}$ \\
\hline$>34$ weeks & $982(66.71 \%)$ & $207(21.07 \%)$ & $29(2.95 \%)$ \\
\hline
\end{tabular}

Table-3: Birth weight of preterm newborns.

\begin{tabular}{|l|l|l|l|}
\hline Birth weight of the newborn & \multicolumn{1}{|c|}{$\begin{array}{c}\text { Total } \\
\text { delivered }\end{array}$} & $\begin{array}{c}\text { Admitted in } \\
\text { NICU }\end{array}$ & Death \\
\hline $\begin{array}{l}\text { Extremely low birth weight (ELBW: } \\
<1000 \mathrm{gm})\end{array}$ & $64(4.35 \%)$ & $64(100 \%)$ & $\begin{array}{l}46 \\
(71.87 \%)\end{array}$ \\
\hline $\begin{array}{l}\text { Very low birth weight (VLBW): } \\
1000-1499 \mathrm{gm}\end{array}$ & $\begin{array}{l}267 \\
(18.14 \%)\end{array}$ & $207(77.52 \%)$ & $\begin{array}{l}67 \\
(25.09 \%)\end{array}$ \\
\hline
\end{tabular}




\begin{tabular}{|l|l|l|l|}
\hline $\begin{array}{l}\text { Low birth weight (LBW): 1500- } \\
2499\end{array}$ & $\begin{array}{l}890 \\
(60.46 \%)\end{array}$ & $\begin{array}{l}257 \\
(28.87 \%)\end{array}$ & $46(5.16 \%)$ \\
\hline Normal birth weight: >=2500gm & $\begin{array}{l}250 \\
(16.98 \%)\end{array}$ & $17(6.8 \%)$ & $5(2 \%)$ \\
\hline
\end{tabular}

257 (47.16\%) were LBW and 17 (3.12\%) had normal birth weight. Statistically, a significant association was seen between the NICU admission with gestational age and birth weight $(p<0.5)$ i.e. NICU admissions increased with decreasing gestational age and birth weight of preterm. A negative correlation was noted between the duration of stay and gestational age of preterm neonate $(r=0.98, p=0.022)$ i.e. as the gestational age increases, the duration of stay in NICU decreases.

Morbidity profile of preterm admitted in NICU was as follows, $303(55.59 \%)$ had respiratory distress syndrome, 167 (30.64\%) had sepsis, 61 (11.19\%) had perinatal asphyxia, $58(10.64 \%)$ had neonatal hyperbilirubinemia, $54(9.91 \% \%)$ had retinopathy of prematurity and 17 cases (3.12\%) had meningitis.
Out of 1472 study subjects, $1200(81.52 \%)$ were discharged, 164 (11.14\%) died and 108 (7.34\%) were discharged on request or left against medical advice. Of the 164 preterms who died in NICU during their treatment, $46(8.54 \%)$ weighed $<1000$ gm, 67 (40.85\%) weighed between 1000-1499 gm, $46(28.05 \%)$ weighed between $1500-2499 \mathrm{gm}$ and 5 weighed more than $2500 \mathrm{gm}$ at the time of birth. Maximum number of deaths were seen in gestational age $<28$ weeks that is $23(67.64 \%)$, $112(36.84 \%)$ in $28-34$ weeks and $29(14 \%)$ in > 34 weeks.

The major cause of death in preterm babies according to gestational age is as follows: in babies $<28$ weeks, prematurity $(82.6 \%)$ was found to be the major cause, followed by RDS (48.21\%) in 28$34 \mathrm{wks}$ and sepsis $(51.72 \%)$ in $>34 \mathrm{wks}$. The cause of death in preterm neonates according to weight were as follows: the major cause of death in babies weighing $<1000 \mathrm{gm}$ was prematurity $(93.61 \%)$, in $1000 \mathrm{gm}$ - $1499 \mathrm{gm}$ was RDS $(67.64 \%), 1500-$ $2499 \mathrm{gm}$ was sepsis $(47.72 \%)$ and $\geq 2500 \mathrm{gm}$ was also sepsis (40\%).

Table-4: Morbidity and Mortality profile of preterm babies according to gestational age.

\begin{tabular}{|c|c|c|c|c|c|c|c|}
\hline $\begin{array}{l}\text { Complication causing } \\
\text { death }\end{array}$ & $\begin{array}{l}<28 w k s \\
(N=23)\end{array}$ & $\begin{array}{l}\text { 28-34wks } \\
(\mathrm{N}=112)\end{array}$ & $\begin{array}{l}>34 \mathrm{wks} \\
(\mathrm{N}=29)\end{array}$ & $\begin{array}{l}\text { Complication causing } \\
\text { morbidity }\end{array}$ & $\begin{array}{l}<28 w k s \\
(N=34)\end{array}$ & $\begin{array}{l}\text { 28-34wks } \\
(\mathrm{N}=304)\end{array}$ & $\begin{array}{l}>34 \mathrm{wks} \\
(\mathrm{N}=206)\end{array}$ \\
\hline $\begin{array}{l}\text { Respiratory distress syndrome } \\
\text { (RDS) }\end{array}$ & 2 & 54 & 3 & $\begin{array}{l}\text { Respiratory distress } \\
\text { syndrome }\end{array}$ & 30 & 256 & 17 \\
\hline Sepsis & 2 & 27 & 15 & Sepsis (EOS) & 13 & 100 & 54 \\
\hline Prematurity & 19 & 25 & 0 & Perinatal asphyxia & 2 & 21 & 38 \\
\hline IVH & 0 & 1 & 7 & Neonatal jaundice & 5 & 29 & 24 \\
\hline NEC & 0 & 3 & 1 & Retinopathy of prematurity & 10 & 44 & 0 \\
\hline Congenital anomaly & 0 & 2 & 1 & Meningitis (LOS) & 0 & 5 & 12 \\
\hline $\begin{array}{l}\text { Persistent pulmonary } \\
\text { hypertension }\end{array}$ & 0 & 0 & 2 & Others & 3 & 30 & 15 \\
\hline
\end{tabular}

Table-5: Mortality and morbidity profile according to birth weight.

\begin{tabular}{|c|c|c|c|c|c|c|c|c|c|}
\hline Complication & $\left|\begin{array}{c}<1000 g \\
m\end{array}\right|$ & $\begin{array}{c}1000- \\
1499 \mathrm{gm}\end{array}$ & $\begin{array}{c}1500- \\
2499 \mathrm{gm}\end{array}$ & $\begin{array}{c}\geq 2500 \mathrm{~g} \\
\mathrm{~m}\end{array}$ & Cause of death & $\left|\begin{array}{c}<1000 g \\
m\end{array}\right|$ & $\begin{array}{c}1000- \\
1499 \mathrm{gm}\end{array}$ & $\begin{array}{c}1500- \\
2499 \mathrm{gm}\end{array}$ & $\begin{array}{c}>=2500 \mathrm{gm} \\
(N=5)\end{array}$ \\
\hline & $(\mathrm{N}=63)$ & $(\mathrm{N}=208)$ & $(\mathrm{N}=257)$ & $(N=17)$ & & $(\mathrm{N}=47)$ & $(\mathrm{N}=68)$ & $(\mathrm{N}=44)$ & \\
\hline $\begin{array}{l}\text { Respiratory distress } \\
\text { syndrome }\end{array}$ & 59 & 187 & 57 & 0 & $\begin{array}{l}\text { Respiratory distress syndrome } \\
\text { (RDS) }\end{array}$ & 0 & 46 & 13 & 0 \\
\hline Sepsis (EOS) & 25 & 78 & 59 & 5 & Sepsis & 1 & 20 & 21 & 2 \\
\hline Perinatal asphyxia & 1 & 8 & 48 & 4 & Prematurity & 44 & 0 & 0 & 0 \\
\hline Neonatal jaundice & 7 & 20 & 30 & 1 & IVH & 0 & 0 & 7 & 1 \\
\hline $\begin{array}{l}\text { Retinopathy of } \\
\text { prematurity }\end{array}$ & 14 & 40 & 0 & 0 & NEC & 2 & 1 & 1 & 0 \\
\hline Meningitis (LOS) & 0 & 6 & 9 & 2 & Congenital anomaly & 0 & 1 & 1 & 1 \\
\hline Others & 5 & 22 & 16 & 5 & $\begin{array}{l}\text { Persistent pulmonary } \\
\text { hypertension }\end{array}$ & 0 & 0 & 1 & 1 \\
\hline
\end{tabular}




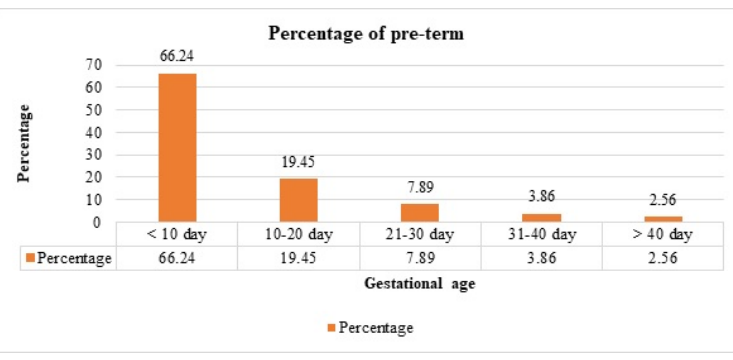

Fig-1: Representing a negative co-relation between Gestational age and duration of stay.

Table-6: Correlation between Gestational age and duration of stay in the NICU.

\begin{tabular}{|c|c|c|c|}
\hline \multicolumn{4}{|c|}{ Correlations } \\
\hline & & DAYS & GA \\
\hline \multirow[t]{3}{*}{ DAYS } & Pearson Correlation & 1 & $-.098^{*}$ \\
\hline & Sig. (2-tailed) & & .022 \\
\hline & $\mathrm{N}$ & 542 & 542 \\
\hline \multirow[t]{3}{*}{ GA } & Pearson Correlation & $-.098 *$ & 1 \\
\hline & Sig. (2-tailed) & .022 & \\
\hline & $\mathrm{N}$ & 542 & 542 \\
\hline
\end{tabular}

There was a negative correlation between the two variables, $r=0.98, p=0.022 . "$

This means that as the gestational age of the newborn increases the duration of stay in NICU decreases.

\section{Discussion}

In the present study, preterm male newborns (54\%) were slightly more as compared to female newborns $(46 \%)$. This was in accordance with the studies by McGregor JA et al (1992) who conducted a cohort study in Denver, North America, and Jennifer et al who conducted a cohort study in France. In the present study, parity does not appear to play an important role in the occurrence of preterm birth. While some studies have reported a slightly increased risk for both first births and higher-order births, others have found either an increase or a decrease in the risk of preterm birth with increasing parity [23-28].

In the present study, 418 (28.40\%) were reported to have complications during pregnancy. Of that, the most common was multiple pregnancies (28.46\%) and pre-eclampsia (27.03\%). Kurdi AM et al (2004) noted that preterm delivery remains the most serious complication of multiple pregnancies. Murray, SR et al (2018) from the University of
Edinburgh, UK, reported that prematurity is the main contributor for twin pregnancies, and twin pregnancies are associated with a three-fold greater perinatal mortality than singleton pregnancies.

The major morbidities noted in preterm neonates were: respiratory distress syndrome (55.59\%), early-onset sepsis (30.64\%), perinatal asphyxia $(11.19 \%)$, neonatal jaundice (10.64\%) and retinopathy of prematurity (9.91\%). Rubaltelli et al [1998] Florence, Italy, and reported that the occurrence of respiratory distress was $20.6 \%$ at $33-$ 34 weeks and $7.3 \%$ at 35-36 weeks [29]. S Shrestha et al (2010) from Nepal, reported that the common morbidities were clinical sepsis (66.7\%), hyperbilirubinemia (58.8\%), birth asphyxia (26.8\%) and hyaline membrane disease (23.5\%) [30] Atasay et al (2010), İstanbul, Turkey reported that respiratory distress was seen in $30 \%$ of late preterm infants [31] Kalyoncu O et al (2010) conducted a study in Turkey and found a significantly increased rate of respiratory problems among late preterm infants compared to term infants [32] Shankar Narayan et al 2002 New Delhi, India evaluated the morbidity and mortality in extremely low birth weight neonates (ELBW) from a tertiary care hospital over seven years (1994-2000) and found that the most commonly encountered morbidities were hyperbilirubinemia (65\%), respiratory distress $(65 \%)$, sepsis $(52 \%)$, intraventricular haemorrhage (29\%), pneumonia (25\%) and retinopathy of prematurity (24\%). Sepsis accounted for $41 \%$ of all deaths while immaturity was the second most important cause, accounting for $24 \%$ deaths.

Poudel P et al (2009) Eastern Nepal reported that the common morbidities among VLBW babies were clinical sepsis (77.1\%), hyperbilirubinemia (73.6\%), apnoea $(48.6 \%)$, shock $(42.9 \%)$, hypoglycemia (39.3\%), anemia (29.3\%), hyaline membrane disease (HMD, 21.4\%), patent ductus arteriosus $(15.0 \%)$, severe hypothermia $(12.1 \%)$, cultureproven sepsis $(15.7 \%)$, retinopathy of prematurity $(5.7 \%)$, and bronchopulmonary dysplasia (3.6\%). Overall survival was $54.3 \%$ and major causes of death were HMD (51.0\%) and sepsis (34.7\%).37Jaiswal et al (2011)Hyderabad, India noted that late preterm infants were at significantly higher risk for overall morbidity due to any cause $(P<0$. 001), any ventilation (non-invasive or invasive $\quad(P=0.001)$ jaundice $(P<0.001)$, hypoglycemia $(P<0.001)$, and probable sepsis $(P<0.001)$. 
Of the 1472 preterm study subjects, $11.14 \%$ died. Maximum deaths (44\%) occurred in very low birth weight newborns and 33\% deaths were noted in 2830 weeks of gestational age. Birth weight and gestational age of newborns were significantly associated $(p=0.000)$ with the treatment outcome. S Shrestha et al (2010), from Nepal, reported that overall survival was $79.4 \%$ in preterm newborns with a minimum age of survival of 880 grams. The mortality rate isthe extremely low birth rate and a very low birth rate was $80 \%$ and $39.5 \%$ respectively. [33], Marchant $\mathrm{T}$ et al (2012) East Africa had reported that $52 \%$ of neonatal deaths occurred in preterm or small for gestational age babies. Babies born $<34$ weeks gestation had the highest odds of death compared to term babies [34], Iyoke C A et al (2014), southeast Nigeria reported that the adjusted perinatal mortality rate for preterm babies in the study center was $46.1 \%$ (236/512) [35].

A total of 545 preterms were admitted in NICU and the common causes of death were RDS $(10.83 \%)$, sepsis $(8.07 \%)$, prematurity $(8.07 \%)$, IVH $(1.47 \%)$, NEC $(0.73 \%)$ and PPHN (0.37\%). AT Bang et al (2005) Gadchiroli, India, reported in the cohort of 763 neonates, 40 neonatal deaths occurred, the morbidities were preterm birth $62.5 \%$; sepsis $60 \%$; intrauterine growth restriction (IUGR) 27.5\%; perinatal asphyxia 25\%; hypothermia $22.5 \%$ and feeding problems $15 \%$ [36]. S Shrestha et al (2010)Nepal, reported that the common causes of death were hyaline membrane disease (64.5\%), sepsis $(58.06 \%)$, and necrotizing enterocolitis (25.8\%). [33]Jack Jacob et al (2010) reported that the most common cause of death was extreme prematurity or low birth weight (14\%). The second and third most common causes of death were sepsis $(12 \%)$ and acquired bowel disease (11\%). Other primary causes of death included lung hypoplasia $(9.5 \%)$, IVH $(9.4 \%)$, respiratory distress syndrome $(8.0 \%)$, hypoxic-ischemic encephalopathy $(6.1 \%)$, major heart defects $(3.4 \%)$.

\section{Conclusion}

This was a prospective observational study which was conducted in the Pediatric Department of Dr. B R Ambedkar Memorial Hospital Raipur from March 2018 - March 2019. A total of 1472 preterm babies born over this period were taken in the study and information of their medical records was analyzed to evaluate the short-term outcomes and risk factors of preterm birth.
The most common maternal risk factors noted were multiple pregnancies, preeclampsia, eclampsia, antepartum hemorrhage, and gestational hypertension. Common morbidities observed in preterm babies were respiratory distress syndrome, sepsis, perinatal-asphyxia, and neonatal-jaundice. Preterm newborns were admitted to NICU and the mortality rate was $11.14 \%$. Two third of the preterm newborns admitted in the NICU was $<1500 \mathrm{~kg}$. The common causes of death were respiratory distress syndrome, sepsis, and prematurity. Findings show that preterm babies have a higher risk of morbidity and mortality. The mortality rate decreased with an increase in gestational age and in babies with increasing birth weight.

\section{What does the study add to the existing knowledge?}

In spite of the advances made in antenatal care and neonatal services, preterm birth still remains an economic as well as emotional burden to the families. In low resource settings empowering the primary care providers with adequate knowledge with an emphasis on the prevention of preterm births, identification of risk factors, avoiding late referrals will benefit. Strengthening the referral system to make sure that high-risk patients are managed in tertiary obstetric units with level 3 NICU facilities will improve the neonatal outcome of these babies who are" Born too Soon" to a great extent.

\section{Author's contribution}

Dr. Sharja Phuljhele: Concept, study design. Dr. Prachi Bichpuria: Manuscript writing. Dr. Samreen Yusuf: Statistical analysis. Dr. Abha Singh: Manuscript writing

\section{Reference}

01. Ahumada-Barrios ME, Alvarado GF. Fatores de Risco para partoprematuroem um hospital. Revista Latino-Americana de Enfermagem. 2016;24;e2750.

doi: $10.1590 / 1518-8345.0775 .2750 \quad$ [Crossref]

02. Trønnes H, Wilcox AJ, Lie RT, Markestad T, Moster D. Risk of cerebral palsy in relation to pregnancy disorders and preterm birth- a national cohort study. Dev Med Child Neurol. 2014;56(8)779-785.

doi: $10.1111 / \mathrm{dmcn} .12430$ [Crossref] 
03. Meza-Martínez J. Maternal factors related to the preterm term and its impact on the newborn, Hipólito National Hospital Nanue- 2002-2006. Peruvian Mag Obstet Nurs. 2007;19;3(2).

[Crossref]

04. Lawn JE, Wilczynska-Ketende K, Cousens SN. Estimating the causes of 4 million neonatal deaths in the year 2000. Int J Epidemiol. $2006 ; 35(3) 706-718$.

doi: $10.1093 /$ ije/dyl043 [Crossref]

05. Goldenberg RL, Culhane JF, Iams JD, Romero R. Epidemiology and causes of preterm birth. The Lancet. 2008;371(9606)75-84.

doi: $10.1016 / s 0140-6736(08) 60074-4$ [Crossref]

06. Rees S, Inder T. Fetal and neonatal origins of altered brain development. Early Hum Dev. 2005;81(9)753-761.

doi: 10.1016/j.earlhumdev.2005.07.004 [Crossref]

07. Jobe AH, Bancalari E. Bronchopulmonary dysplasia. Am JRespirCrit Care Med. 2001;163(7)1723-1729.

doi: $10.1164 /$ ajrccm.163.7.2011060 [Crossref]

08. Henderson JJ, McWilliam OA, Newnham JP, Pennell CE. Preterm birth aetiology 2004-2008, Maternal factors associated with three phenotypes- spontaneous preterm labour, preterm pre-labour rupture of membranes and medically indicated preterm birth. J Matern Fetal Neonatal Med. 2012;25(6)642-647.

doi: 10.3109/14767058.2011.597899 [Crossref]

09. Conde-Agudelo A, Rosas-Bermúdez A, KafuryGoeta AC. Birth spacing and risk of adverse perinatal outcomes- a meta-analysis. JAMA. $2006 ; 295$ (15)1809-1823.

doi: 10.1001/jama.295.15.1809 [Crossref]

10. Kramer MS, Demissie K, Yang $H$, Platt RW, Sauvé R, Liston R. Fetal and Infant Health Study Group of the Canadian Perinatal Surveillance System, The contribution of mild and moderate preterm birth to infant mortality. JAMA. 2000;284(7)843-889.

Doi: 10.1001/jama.284.7.843 [Crossref]
11. Raju TN. The problem of late-preterm (nearterm) births- a workshop summary. Pediatr Res. $2006 ; 60(6) 775-776$.

doi: $\quad 10.1203 / 01 . p d r .0000246074 .73342 .1 \mathrm{e}$ [Crossref]

12. Wang $M L$, Dorer DJ, Fleming MP, Catlin EA. Clinical outcomes of near-term infants. Pediatr. 2004; 114(2)372-376.

doi: 10.1542/peds.114.2.372 [Crossref]

13. Kinney HC. The near-term (late preterm) human brain and risk for periventricular leukomalacia- a review. In Seminars in perinatology 2006, WB Saunders. 2006;30(2)81-88.

[Crossref]

14. Escobar GJ, McCormick MC, Zupancic JA, Coleman-Phox K, Armstrong MA, Greene JD, et al. Unstudied infants- outcomes of moderately premature infants in the neonatal intensive care unit. Arch Dis Child Fetal Neonatal Ed. 2006;91(4)F238-F244.

doi: $10.1136 \% 2 F a d c .2005 .087031 \quad$ [Crossref]

15. Roberts D, Brown J, Medley N, Dalziel SR. Antenatal corticosteroids for accelerating fetal lung maturation for women at risk of preterm birth. Cochrane Database Syst Rev. 2017;3(3) CD004454. doi: 10.1002/14651858.cd004454.pub3 [Crossref]

16. Soll RF. Surfactant treatment of the very preterm infant. Neonatol. 1998;74(1)35-42. doi: $10.1159 / 000047033$ [Crossref]

17. Gultom E, Doyle LW, Davis P, Dharmalingam A, Bowman $E$. Changes over time in attitudes to treatment and survival rate for extremely preterm infants (23-27 weeks' gestational age). Aust N Z JObstet Gynaecol. 1997;37(1)56-58. doi: 10.1111/j.1479-828x.1997.tb02218.x [Crossref]

18. Doyle LW, Rogerson S, Chuang SL, James $M$, Bowman ED, Davis PG. Why do preterm infants die in the 1990s. Med J Aust. 1999;170(11)52832. doi: 10.5694/j.1326-5377.1999.tb127877.x [Crossref]

19. Draper ES, Manktelow B, Field DJ, James D. Prediction of survival for preterm births by weight and gestational age- retrospective population-based study. BMJ. 1999;319(7217)

1093-97. doi: 10.1136\%2Fbmj.319.7217.1093 
20. Hagan $R$, Benninger $H$, Chiffings $D$, Evans $S$, French $N$. Very preterm birth-A regional study, Part 2- The very preterm infant. BJOG- Int J Obstet Gynaecol. 1996;103(3)239-245. doi: 10.1111/j.1471-0528.1996.tb09712.x [Crossref]

21. Doyle LW. Outcome at 5 years of age of children 23 to 27 weeks' gestation- refining the prognosis. Pediatr. 2001;108(1)134-141. doi: 10.1542/peds.108.1.134 [Crossref]

22. Sugantha R, Nanthini N, Padmanaban S. Evaluation of nifedipine tocolysis in preterm labour. Int J Clin Obstet Gynaecol. 2019;3(2)7678.

doi: $\quad 10.33545 /$ gynae.2019.v3.i2b.223 [Crossref]

23. Shiono $\mathrm{PH}$, Klebanoff MA. Ethnic differences in preterm and very preterm delivery. Am J Public Health. $1986 ; 76(11) 1317-1321$.

doi: $\quad 10.2105 \% 2 F a j p h .76 .11 .1317$ [Crossref]

24. Pickering RM, Deeks JJ. Risks of delivery during the 20th to the 36th week of gestation. Int J Epidemiol. 1991;20(2)456-466.

doi: $10.1093 / \mathrm{ije} / 20.2 .456$ [Crossref]

25. de Sanjose S, Roman E. Low birthweight, preterm, and small for gestational age babies in Scotland, 1981-1984. J Epidemiol Comm Health. $1991 ; 45(3) 207-210$.

doi: $10.1136 \% 2 F j e c h .45 .3 .207$ [Crossref]

26. Papiernik E. The principal risk factors for preterm delivery. Effective prevention of preterm birth- the French experience measured at Haguenau. $1989 ; 29-37$.

[Crossref]

27. Meyer MB, Jonas BS, Tonascia JA. Perinatal events associated with maternal smoking during pregnancy. Am J Epidemiol. 1976;103(5)464476.

doi: 10.1093/oxfordjournals.aje.a112248 [Crossref]

28. Mamelle N, Laumon B, Lazar P. Prematurity and occupational activity during pregnancy. Am J Epidemiol. 1984;119(3)309-322.

doi: 10.1093/oxfordjournals.aje.a113750 [Crossref]
29. Rubaltelli FF, Bonafè L, Tangucci M, Spagnolo A, Dani C. Epidemiology of neonatal acute respiratory disorders. Neonatol. 1998;74(1)715.

doi: $10.1159 / 000014005 \quad$ [Crossref]

30. Bang AT, Reddy HM, Bang RA, Deshmukh MD. Why do neonates die in rural Gadchiroli, India? (Part II)- estimating population attributable risks and contribution of multiple morbidities for identifying a strategy to prevent deaths. J Perinatol. 2005;25(1)S35-S43.

doi: $10.1038 /$ sj.jp.7211270 [Crossref]

31. Atasay B, Okulu E, MunganAkın İ, Çandır O, Arsan S, Türmen T. The early clinical outcomes of late preterm newborns. Turkish J Pediatric Dis. $2010 ; 4 ; 30-35$.

[Crossref]

32. Kalyoncu Ö, Aygün C, Çetİnoğlu E, Küçüködük S. Neonatal morbidity and mortality of latepreterm babies. J Mat-Fet Neonat Med. $2010 ; 23(7) 607-612$.

doi: $10.3109 / 14767050903229622$ [Crossref]

33. Shrestha S, Dangol SS, Shrestha M, Shrestha RP. Outcome of preterm babies and associated risk factors in a hospital. J Nepal Med Assoc. 2010;50(180)286-290.

[Crossref]

34. Marchant T, Willey B, Katz J, Clarke S, Kariuki S, Ter Kuile F, et al. Neonatal mortality risk associated with preterm birth in East Africa, adjusted by weight for gestational ageindividual participant level meta-analysis. PLoS medicine. 2012;9(8)e1001292.

doi: 10.1371/journal.pmed.1001292 [Crossref]

35. Iyoke CA, Lawani OL, Ezugwu EC, Ilechukwu G, Nkwo PO, Mba SG, et al. Prevalence and perinatal mortality associated with preterm births in a tertiary medical center in South East Nigeria. Int JWomen's Health. 2014;6;881-888. doi: $10.2147 /$ ijwh.s72229 [Crossref]

36. Cupen K, Barran A, Singh V, Dialsingh I. Risk factors associated with preterm neonatal mortality- a case study using data from Mt. Hope Women's Hospital in Trinidad and Tobago. Children. 2017;4(12)108.

doi: $10.3390 /$ children4120108 [Crossref] 
37. Poudel P, Budhathoki S, Shrivastava MK. Maternal risk factors and morbidity pattern of very low birth weight infants- A NICU based study at eastern Nepal. J Nepal Paediatr Soc. $2009 ; 29(2) 59-66$.

doi: $10.3126 /$ jnps.v29i2.2040 [Crossref] 